\title{
The Symbolic Meaning of Galombang Duo Baleh in Sintuk Communities Padang Pariaman Sumatera Barat
}

\author{
Darmawati $^{1}$ and Herlinda Mansyur ${ }^{2}$
}

\author{
${ }^{1}$ Universitas Negeri Padang, Padang, Indonesia, $ه$ (email), darmawati@fbs.unp.ac.id \\ ${ }^{2}$ Universitas Negeri Padang, Padang, Indonesia, $\triangle$ (email), mamigaung@yahoo.com
}

\begin{abstract}
Galombang duo baleh is a traditional art found in the Pariaman community in general and the Sintuk community in particular in West Sumatra. The purpose of the study is to examine the values in Galombang duo baleh in which this art is an activity in various Alek of Sintuk societies that has symbolic elements. The method used is the ethnographic method. Data from this study are qualitative data collected through observation, interviews, and literature studies. Data analysis was carried out by determining objects, conducting compound analysis, and conducting focused analysis. Putting values through Galombang duo baleh makes Galombang duo baleh a part of the Sintuk community's tradition which is displayed to welcome guests. In the appearance of Galombang duo baleh, there are several elements, such as: dancers, movements, floor patterns, music and musicians, costumes, and equipment in the form of traditional objects (marawa and carano containing complete betel), and venues. The results show that the symbolic meaning of Galombang duo baleh is as a description of sincerity in accepting guests began with alertness, vigilance with toughness in a compact manner in a vigorous step to always lead forward to save the village or the nagari.
\end{abstract}

\section{Keywords: Galombang duo baleh, Symbolic Meaning, traditional dance of Minangkabau}

\section{INTRODUCTION}

Galombang duo baleh is a traditional art that grows, lives, and develops in the society of Sintuk Padang Pariaman, West Sumatra province. It was inherited from a predecessor generation that is said to have existed long before the independence era. The creation of this art is as a representation of the cultural values they profess. Galombang duo baleh was created and used by the Sintuk community to welcome honored guests at a big party or event called 'alek nagari' (a party of the people) in the context of the coronation of the headman and the inauguration of new buildings, such as offices, schools and mosques. .

This art is performed by men, both those who do the movements, marawa carrier, carano performers, and music players. The movements carried out in Galombang duo baleh are based on pencak silat elements which are dominated by the steps and accompanied by the music of Tambua music. The Galombang duo baleh is displayed on the road in front of the venue of the event to welcome visitors.

Galombang duo baleh, according to Sintuk community as a supporter of this art, has certain values or meanings. Something that is valuable is something that can contribute to society. Likewise, the Galombang duo baleh dance contributes to the Sintuk community in instilling the values held by the community. This art is performed in a crowd event to welcome guests, who at that time are attended by many members of the community, both from the guest side and the guest waiting party. Community members come together to attend the event. When guests arrive, all members of the community who attend witness the performance of Galombang, such as joining together in Galombang duo baleh, so that none of the community members act out of politeness. All presents give room for guests after being welcomed by Galombang duo baleh and accompanied together to the seats that have been provided. Togetherness values appear to emerge, and this is the contribution of Galombang duo baleh to the community.

Yulianti (2015) said that value is something that is understood by the community about what is meaningful that can be interpreted by the community towards the contribution of something to people's lives. Yulianti sees that, for example from the aspect of history, history will be valuable if it can be understood by society, and history itself gives meaning and contribution to society. Like art, it will be valuable if it can provide something valuable and beneficial to society, whether its benefits, meaning given, or knowledge that will be absorbed by the community. Then something will be valued if the value is attached to what will be valued.

Galombang duo baleh as a traditional art which is the cultural identity of the Sintuk community, is seen by the majority of the community it contains values that can be useful and utilized in regulating the behavior of community members. Thus, Galombang duo baleh art is considered something important and meaningful by the 
community. Therefore, every event that welcomes honored guests, the Galombang duo baleh performance becomes an activity in the event. According to Spradley (1997: 5), in every society, people still use a complex meaning system to regulate their behavior, to understand themselves, to understand others, and to understand the world in which they live.

Aini (2014) said that the values contain elements of balance that carry individual ideas about things that are true, good, and desirable. Values have contents and intensity. The nature of the content conveys that the manner of implementation or the final state of life is important. The nature of intensity explains how important that is. This means that value is a belief about something that is understood and interpreted based on behavior or symbols and characteristics of humans and things. Value also refers to the meaning of a person against the behavior and activities or the meaning of an activity and the meaning of an object that is considered to have something that is considered valuable.

Indrayuda (2017) said that an art will remain in its owner community if the art is useful with its civilization both for the past, present, and future. In addition, an art will survive, grow, and develop in a long time in the midst of community life if the art has norms and values that are the same as the values adopted by the supporting community. In addition, the art also has universal values that are relevant to human life.

Referring to the grand tour that researchers did in Sintuk, in fact the Sintuk people still maintain the existence of Galombang duo baleh as their cultural heritage. This is seen from the people's understanding of the art which has norms and procedures for interacting with others. It is in a polite setting and being alert in welcoming guests. Therefore, in Galombang duo baleh there are values that are understood as meaningful for traditional leaders, galombang actors, and the general public.

Art work is a long thought of people who have expertise in interpreting a condition of community behavior, as is often done by the community who then adapt it to the form of cultural arts through the creativity process of the artists. In addition, many works of art are influenced by the power of thought and human behavior. If humans are still consistent in carrying out their customs and local values in the arts by realizing these arts, then these values will indirectly persist even though creativity has influenced humans (Kudiya, Komarudin., Setiawan S., and Agus S, 2016).

Until now, Galombang duo baleh's performance is still performed to welcome guests of honor, but events like those mentioned above have rarely been held. This is due to the economic factors of Sintuk's people who have begun to decline, so that a large event (alek nagari) is rarely held. In addition, the inauguration ceremony of the building has also been very rarely carried out. This has increasingly made Galombang duo baleh lose its passion in the sense of decreasing the intensity of performance. With this condition, it can be said that the role of Galombang duo baleh dance in conveying the values adopted by the community has begun to decline, which is feared at the end it will disappear. The continuity of these values is due to the continuing Galombang duo baleh dance performance. It means that the local values adopted by the people in Galombang duo baleh which are always attached to every show will continue to be related to their human activities. But it can also be suspected if the Galombang duo baleh dance continues to be performed in the alek nagari event to welcome guests, but there is also a possibility that the values contained will be lost from the Galombang duo baleh dance. Sustainability of the values adopted by the community is not only related to the Galombang duo baleh performance but can also be said to be related to the people. One effort was made to trace these meaningful values through these studies, namely the study of symbolic meanings. The representation of values that are adopted by the community is found in the structure of the Galombang duo baleh performance through various elements in the form of symbols.

As for the discussion of several books, theses, and journals discussing Galombang duo baleh, there is no discussion found similar to the discussion discussed in this paper-symbolic meaning. Meaning is the purpose of discussion (Ministry of Education and Culture, 2001). Thus, symbolic is about the use of symbols (symbols) to express ideas (eg literary, artistic) (Sugono, 2008). Furthermore, Tunggal said (in Ida Kusumawardani 2013: 3) symbols are indirect representations of the most important meaning for example in religion, ritual and dance.

Previous research conducted by Dina Mutiatul and Darmawati (2018) about Galombang duo baleh has been written in an article entitled "Forms of Presentation of Galombang duo baleh in the Marunggi Marriage Party in Pariaman city". The study focused on the form of the Galombang duo baleh dance that was performed to welcome the arrival of the bride. Overall, the Galombang duo baleh form consists of elements: motion and dancers, music and performers, costumes, floor patterns, and performance equipment. In other writings, the results of the study generally inform about the use of the Galombang dance in marriage ceremonies and their development. The same principle is also said by Navis (in O'ong Maryono 1998: 217-218), that:

"Galombang dance is a ceremonial dance that is performed at a marriage ceremony or coronation ceremony of the prince. The cast consists of dozens of men who are divided into two guards - the guards of the guest group and the host's bodyguards - each led by a tuo who gives the signal and is accompanied by sounding instruments such as talempong and flute (made from rice stem). Gaombang dancers overtake guest groups by stepping up pencak. Every time they want to make a step forward, they clap with their leaders as two warriors who want to fight. Movement lowers when stepping legs wide, then rises by lifting one leg almost knee-high like a wave. The difference is that the two groups do not make attacks or fend off movements, such as pencak players in situations of reconnaissance of the opponent's steps." 
The part that can be taken into data is in terms of its use, which is to welcome guests, likewise about the elements in the performance which contains main element (movements with dancers) and supporting elements (floor patterns, music, costumes, and completeness of the performances). These things are as data to guide the elements contained in Galombang duo baleh which are symbols in realizing values that have meaning for the Sintuk community as supporters of this art.

Geertz theory (in Kusumastuti which was adapted by Ida Kusumawardani 2013) for analyzing symbolic meaning in this writing provides an in-depth explanation of meaning as everything (actions, speech gestures and objects that mark or represent something. This theory is complemented by Putra's opinion (2013) 2000: 400) who said that in analyzing art, it is focused on textual studies, which are studies that look at the phenomenon of art as a stand-alone text and contextual studies that place the phenomenon in a broader context, namely the socio-cultural context of the community in which the phenomenon. It is reinforced by the theory put forward by (Kipli 2009: 4) that meanings can only be obtained through analysis of one community group, which is called a homogeneous audience. It means that it is only the supporters of the art, for visitors from outside in general do not understand the values of performance formed with many symbols.

\section{METHOD}

This research was conducted qualitatively, because the researcher revealed the cultural meaning and symptoms of culture, namely the symbolic meaning contained in the Galombang duo baleh performance. The study of the meaning is examined from anthropological aspects, namely regarding sustainability and representation. Therefore the method used is a descriptive method that describes the phenomena that emerge from the Galombang duo baleh performance as the cultural heritage of the Sintuk Padang Pariaman community.

The research instrument is the researcher itself as a key instrument, which is equipped with observation guidelines and interview guidelines, so that the researcher can systematically trace the desired qualitative data in accordance with the research problem. Researchers' data was collected through direct observation, interviews, literature review and documentation review. The data collected is data from the Galombang duo baleh performance, data from community activities of Galombang duo baleh actors both their attitude and behavior in the show and before or after the show and when interacting and integrating with the community. In addition, the data collected was data on community behavior around the Galombang duo baleh performance site, the views of the community or traditional leaders regarding the existence and performances of Galombang duo baleh.

Data were analyzed through data identification, data selection, data presentation, data testing, and data conclusions. The data were selected by looking at the level of suitability of the data with the instruments and research problems. Data testing was done by testing the data source, the level of credibility of the informant, the percentage of homogeneity of the assumptions of the informant, and the interpretation of researchers relevant to the research context.

The validity of the data was carried out by triangulation and cross-checking, as well as discussing with teachers and colleagues. Comparing the perceptions and interpretations of one informant with the teacher's interpretation. The technique used is snowball, which continues to roll to the conclusion that it is sufficiently accurate about the data collected.

\section{RESULT AND DISCUSSION}

A. Galombang duo baleh Performing Arts

Based on Pencak Silat Motion and As a Cultural Statement Galombang duo baleh, in the Sintuk area, is not presented to await guests during a marriage ceremony but to await honored guests in the context of the Archiving ceremony and inauguration of new buildings that are usually inaugurated by government officials. The perpetrators who carried out the movement consisted of twelve men who in their presentation were divided into two groups that moved face to face. Positioning face to face between two groups of dancers plays one group as a guest bodyguard and another group as a host bodyguard. In doing the movement it is led by a tuo to give the signal. The position of the perpetrators of the movement is in front of or ahead of the guests. The two groups facing each other are impressed by two groups of warriors who will fight. Stepping movements for each group always go to the front which when lowering the position of the 'pitunggua' leg position (kuda-kuda) and when the movement rises by resting on one leg (the other leg is lifted). Movement is done repeatedly where low positions alternately with high positions that form the impression of the waves. Pencak movements that are carried out do not attack and fend off movements as contained in the appearance of pencak silat, but the movements that are carried out give the impression of stalking each other's opponent's steps. During the performance of the movements, it is accompanied by the sound of drums consisting of a set of traditional drum musical instruments called "gandang tambua". This is in contrast to the Galombang dance in other areas in Minangkabau which is generally performed to await guests at a wedding party and accompanied by musical instruments consist of various musical instruments, such as talempong and flute (made from rice stems).

Galombang duo baleh, which is generally found in the Pariaman area (including in Sintuk), is presented as a cultural statement for the public to wait for or invited visitors. It is said that the social life of the Pariaman community has always been related to the arrival of foreign nations because according to the geographical location, Pariaman area is around the west coast of West Sumatra facing the Indian Ocean which has large waves. The arrival of foreign nationals to the West Sumatra region is not only peaceful in the context of looking for life but 
also in the form of political control from one country to another and from one area to another in one island. The example is the relationship between Aceh and Minang which has two aspects: looking for life and political control. As we have seen that in ancient times, the travel between countries, between islands, and even between regions of an island through sea links which made Pariaman the entrance for migrants to the dominant West Sumatra area inhabited by the Minangkabau tribe.

The habit of Minangkabau people in equipping themselves with a skill to face challenges is to practice martial arts to the advanced level. Martial arts training is intended for men who practice since teenager's. Within each state unit (in Minangbabau 'Nagari') then the strengths of community groups developed. Each of which has an allocation of authority in directing the development or stabilization of culture.

In addition, the movement (arrival) of the population can make population dynamics that ultimately affect the development of culture (Edi Sedyawati 2012: 329, 337-337). The phenomena that occurred in the past in the Pariaman community, which is the arrival of a foreign nation in the form of political control of the region has clearly had a lot of impact on society, including experiencing challenging things. Then this phenomenon can be suspected as a setting or emergence of the Galombang duo baleh art concept which is a combination of spiritual foundation that animates pencak silat users with experiences in social life that feel threatened by the arrival of foreigners. The users have a spiritual foundation which is to realize the ideals of humanity and noble society in accordance with the values that are held in high esteem by members of the surrounding community (O'ong 1998: 236-249). Likewise with things that can occur in shipping and trade missions (as Edi Sedyawati):

"Shipping and trade in their secondary function as the drivers of cultural dynamics, in part: (1) relations between nations (large and small) result in the enrichment of cultural treasures (at the level of concepts, vocabulary, and technology); (2) the strengthening of group awareness / awareness of cultural identity precisely because it is dealing with various foreign nations. The mission of shipping on the relationship between places in the coastal area includes three possibilities; (1) service, (2) transportation of goods, (3) sea security and warfare "(2012: 334-335).

\section{B. Elements of the Galombang duo baleh Performance}

In the Galombang duo baleh performance in Sintuk as a whole, from the beginning to the end of the show, various elements are included, such as dancers and movements, accompaniment and performers, floor patterns, costumes, and traditional objects as performance equipment. All of these elements in the unity of the Galombang duo baleh form as symbols in the embodiment of the values embraced by society.

i. Dancers and Dance Moves

The perpetrators of the Galombang duo baleh movement or dancers consisted of twelve men. Based on the form, the dancers are divided into two groups. Each consists of six people. Twelve dancers are divided into two groups. Each group consists of six people. According to text, this represents the symbol of the existence of the Sintuk community consisting of groups of people (called tribes) consisting of six tribes, namely: koto, pinyalai, guci, sikumbang, tanjuang, and jambak. In context, the form in Galombang duo baleh symbolized by six dancers shows the meaning that all members of the community are involved in maintaining the security of the village from various threats or hazards, especially the dangers that come from the outside, i.e. people who are considered strangers at one time or one side can be the guest.

The movements used in Galombang duo baleh as mentioned in the previous section are based on pencak silat elements, such as: movement of steps, gelek, gantuang kaki, movements of tutuik hands, claps. Steps are made in the form of zig-zag substances towards the front right oblique direction left front oblique direction. This step move is mostly done in three counts (step three times) and the count of four is followed by foot movement, which is to lift one foot beside the last step foot to support the body. Gelek motion is a motion toward the direction (rotate the body) towards the right and towards the left axis at the waist so that it forms a cross leg and is followed by a pat motion. When moving the steps towards oblique front right and left front alternately with the knees bent in a rather low position pitunggua and when followed by the motion of the gantung kaki the dancer's body position is in a high state which is then continued with the pacing steps until it returns to the leg hanging. The repetitions of steps that ended with hanging legs manifested like waves. Between two repetitions of the footsteps and hanging interspersed with the ripple motion (turning the body) towards the rear which is waving at the waist then the dancers clap three times and then rotate the body again (gelek) towards the front. After the reel, the steps are continued until the positions of the two groups of dancers are close together or close to each other.

The motion in Galombang duo baleh is carried out simultaneously with the position of a straight line by each group consisting of six people facing each other at the beginning of the distance a little far apart. Form of movement that is often or frequently performed in Galombang duo baleh is a movement that always moves forward. The move is like the warriors who are on standby. This is a form of a symbol of togetherness which means that all members of the community in Sintuk have an obligation to protect the village from dangerous threats. Galombang duo baleh is used to attract or wait for guests as an embodiment of the ideas of the community as its creator filled with thoughts about readiness to receive guests. In terms of values adopted by the community which is based on adat basandi sarak, syarak basandi kitabullah, in which guests must be glorified. However, based on the experiences of the people who lived around the seashore in the past, as the creator of Galombang duo baleh, the arrival of foreigners had their own thoughts in responding to the arrival of guests. The guests are indeed obliged to be glorified but not all of them are guests who 
are always and totally well intentioned. Sometimes the person who comes as a guest is tucked inside him of bad intentions. Therefore, it is necessary to be alert with full anticipation in waiting for guests who are in Galombang duo baleh. The dancers need to move together and always go forward, even though for a moment they are in a place with applause - in the form of symbols which means a notice to members of the public about the arrival of the community guest.

\section{ii. Accompanying Music and Music Players}

The performance of the Galombang duo baleh movement is accompanied by the drum beats. This collection of drum instruments accompanying the perfromance of this art is a traditional musical instrument that is typical of the Pariaman community, which belongs to the Sintuk community, namely the 'gandang Tambua'. Gandang Tambua consists of two kinds of drum shapes. Six large drums that have two surfaces covered by skin to beaten are called 'Gandang tambua' and one small drum shaped pot and only one surface covered with skin to be beaten is called 'tasa'. Tasa wasps as the beginning of the sound of music and then followed by the tambua six wasps simultaneously as fillers called tasa sounding tingkah. The joint wasps of the Tambua gandang musical instrument group gave rise to a lively atmosphere that is very supportive of the Galombang duo baleh movement based on pencak silat movements as a symbol in realizing agility. All music players consist of seven men - one tasa player and six tambua players. The musician, the tambua music player who is entirely male, is in accordance with the shape and size of the tambua drum, as large as a drum with a diameter of approximately $60 \mathrm{~cm}$ and a length of approximately $70 \mathrm{~cm}$, which when he plays it is hung on a body with a rope attached to one of shoulder with the drum tilted from top to bottom in front of the body. The tasa drum is played by hanging on the neck with the drum position in front of the body whose surface is covered with skin facing the audience.

\section{iii. Floor Pattern}

It is in accordance with the number of dancers consisting of twelve people as previously mentioned are divided into two groups. The position of the two groups of dancers face to face with a distance of approximately 40 meters with a straight line-shaped floor pattern. The dancers in each group stand in a straight line to the side. The pattern of flooring is always formed from the beginning to almost the end of the appearance, even though the line through which the dancer steps in unison takes the form of a zig substance. The pattern of flooring in the form of two straight line facing each other is very supportive of the concept of the Galombang duo baleh performance in waiting for guests. One group of dancers is in front of people who receive guests, namely as a host and another group of dancers are in front of a group of guests or overtake a group. Both groups of dancers have the same role, which is equally protecting or protecting the people behind them. The dancers in front of the host maintain the safety of the host and the dancers who are in front of the guest group take care of the safety of the guests. The groups of dancers who are in front of the host is a symbolic form as a fortress to maintain the safety of the host with his dexterity that contains the value of vigilance. The group of dancers in front of the guests is also a form of symbol in protecting the group of guests, but it contains the value of caution. That is, when coming to a other people's place, having wisdom in seeing the situation in the place of other people visited is important. It is not using arbitrary attitude which means that caution is needed to maintain safety and a wise attitude in order to adjust to the place of others.

\section{iv. Dance Costume}

The Galombang duo baleh dancers wear costumes like pencak silat performers in Minangkabau which consist of loose pants called 'galembong' pants and also loose clothes that are traditionally black. The use of this costume by the way the bottom of the shirt is inserted into the waist and the pants are rolled up slightly and tied with batik cloth that is formed in a triangle. In the middle corner of the triangular fold is placed face down behind the hip. The form of this costume is clearly a part of the form of the martial arts costume which in the appearance of Galombang duo baleh is a form of the symbol of a warrior who in the sense of someone who has dexterity.

\section{v. Performing Equipment}

In the appearance of Galombang duo baleh, there are completeness consisting of traditional objects as supporting elements, such as: a small flag (marawa kecil in Minang) and a betel place (carano). Marawa was held by a man who is to restrict the dancers whose two rows of lines have approached each other whose positions are almost met. The role of the marawa is as a breakthrough by being put down between two groups of dancers who are approaching. Until now, the flag is still used in the performance of Galombang duo baleh and it can not be said to be abolished. The people supporting Galombang duo baleh still believe in the performances realized by the movements of pencak silat which are impressed by the two groups of dancers lurking at each other. If it is very close there will be mutually attacking and fighting between the warriors. Carano is used to welcome guests by inviting betel leaf as a symbol to manifest a sincere feeling in receiving guests.

\section{vi. Performance venue}

The Galombang duo baleh performance is held on the street near where the event is held. Area of the road where the performance is not a path, but the road can be passed by cars in dispute. The size of the width of the road is in accordance with the needs of the six dancers who are standing parallel. For the position of the dancer when the initial performance requires a distance between 40 to 50 meters. Thus the road as a place passed by people who come and people who will be traveling. The provisions of the Galombang duo baleh performance are an adjustment to the concept of its use, namely to welcome guests with full vigilance. In terms of this concept, the performance of 
Galombang duo baleh to wait for guests is not in the room but on the road in front of the event venue that in principle awaiting guests with Galombang duo baleh is 'welcoming' guests.

\section{Galombang duo baleh Dance Performance Structure Galombang duo baleh performances are in the} form of sequences, which are a series of structured performances consisting of the beginning, core, and end sections. The initial part is the preparation phase. Before the guests arrived the dancers had prepared themselves by wearing Galombang duo baleh costumes. Other members who are members of this art group are the marawa flag holders who before the guest group come to prepare the marawa. Likewise, the group members who are tasked with carrying carano have prepared a complete betel. If according to the estimation, the group of guests will arrive in accordance with the agreement of the previous time, the dancers who are divided into two groups, each group has positioned themselves on the road at the place of carrying visitors. One group is on the road from the direction the guests come and another group on the road near the venue. Likewise, the Tambunan musician music players also prepare themselves, each of which has a drum music instrument. The community members who as the host have also positioned themselves behind the dancers. Community members present at that time as spectators stand on the left and right side of the road that would be passed by the dancers along with a group of guests.

At the core, the Galombang duo baleh is on performance. It is fter the group of guests usually get off the vehicle immediately and stand behind the dancers. In a short time the tambua gandang music starts as an intro which soon the dancers start the movement. The movements carried out by each group are mostly in the form of steps towards the front, then the dancer's initial position which is approximately 40 meters away eventually also approaches the group of guests and slowly walks behind the dancers. When the two groups of dancers have begun to approach a bit, the drum instrument's beats are dynamically raised so that the dancers are impressed that their enthusiasm emerges together toward the front which fosters the impression that the two groups of dancers are lurking more closely, lurking as opposed to each other. Therefore, the holder of the flag of marawa must quickly readily lay down the marawa between two groups of dancers who are very close as a form of divorce and at this time the sound of music stops immediately. After it is laid, the dancers between the two groups shake hands and follow each other by positioning themselves along the road where the group of guests would pass.

At the end, it is the time for the host to approach the guest who is preceded by a carano bearer. The guests are treated to complete betel in carano as a sign of sincerity in receiving guests and then guests are accompanied into the event room and invited to sit. Carano which is a traditional object in Minangkabau for betel places served to guests is naturally civilized as well. The form of carano is used as a complete betel container which is on the top edge of a circular wall about $5 \mathrm{~cm}$ high. The circle at the top edge of this carano is a symbolic statement which has a meaning in Minangkabau, that 'adat selingkar nagari'. That is, if we visit people to other places, it is necessary to have wisdom in adjusting to customs or procedures in the places we visit.

\section{CONCLUSION}

In the function of the show, Galombang duo baleh is as a media in the process of establishing friendship, integration / intimacy between community members, and as a moral or ethical education media welcomes guests and ethics as guests. Galombang duo baleh as a cultural statement has a role in conveying the values adopted by the community; namely the value of ethics, attitude of respect and courtesy. Another important point is the attitude of 'always' maintaining dignity and maintaining the safety of the village with vigilance and resilience. All values are realized by symbols through various elements in the appearance of Galombang duo baleh. Each symbol has a meaning related to a phenomenon of the life of the community supporting this art, namely the Sintuk community.

The usefulness of Galombang duo baleh is only performed when there is an event activity to welcome guests. At the same time, it is also seen that members of the community with a spirit of togetherness are responsive in maintaining good manners, dignity, with full toughness and always being vigilant. This means that when Galombang duo baleh is performed on the event to wait guests, it also comes a sense of responsiveness to the values held in the community. Values that are adopted by the community and always appear in the soul also are caused by the role of Galombang duo baleh in the community. Especially in this era of globalization, community responsiveness is increasingly declining in social and cultural life. Therefore, the Galombang duo baleh show can be a value in the midst of Sintuk society.

\section{REFERENCES}

[1] Abdul Rahman, Mohd. Kipli 2009. Mabuk Mistikal Semiotik Metafizik dalam Kuda Kepang Mabuk. Pulau Pinang: Universiras Sains Malaysia. Siri Kecetakan Akademik

[2] Aini, Nur. 2014. "Internalisasi nilai-nilai pendidikan karakter di MTS Ma'arif SukorejoPasuruan, "Dr. Disertasi, Universitas Islam Negeri maulana malik Ibrahim.

[3] Departemen Pendidikan dan Kebudayaan 2001. Kamus Besar Bahasa Indonesia. Jakarta: Balai Pustaka

[4] Brown, H. Douglas. 2001. Teaching by Principles: An Interactive Approach to Language Pedagogy $2^{\text {nd }}$ edition. New York: Longman.

[5] Dina Mutiatul dan Darmawati 2018. Bentuk Penyajian Galombang duo baleh dalam Upacara Perkawinan di Desa Marunggi Kota Pariaman. Padang: Universitas Negeri Padang 
[6] Hadi, Y. S 2007. Kajian Teks dan Konteks. Yogyakarta: Pustaka Book Publisher

[7] Ida Kusumawardani 2013. Makna Simbolik Tari Sontoloyo Giyanti Kabupaten Wonosobo. Semarang: http//journal.unnes.ac.id/sju/index.php/jst

[8] Indrayuda, "Tari sebagai budaya dan Pengetahuan" Padang UNP Press, 2013.

[9] Kudiya, Komarudin., Setiawan S., dan agus S., "Symbolic Meaning of the Ornamental Diversity of Cirebon Batik Pengajahan, "Jurnal Harmonia 17 (2) (2017)

[10] Moleong, L. J 2005. Metodologi Penelitian Kualitatif. Bandung: PT Remaja Rosdakarya

[11] O’ong Margono 1998. Pencak Silat Merentang Waktu. Jogjakarta: Pustaka Pelajar

[12] Putra, H. S. A 2000. "Wacana Seni Dalam Antropologi Budaya: Tekstual Kontekstual dan Post Modernitas" dalam Ketika Orang Jawa Nyeni. Yogyakarta: Galang Press

[13] Sedyawati, E. 1984. Tari Tinjauan Dari Berbagai Segi. Jakarta: Pustaka Jaya

[14] Sedyawati, E. 2012. Budaya Indonesia: Kajian Arkeologi, Seni, dan Sejarah. Jakarta: Rajawali Pers

[15] Sugono, D. 2008. Kamus Bahasa Indonesia. Jakarta: Pusat Bahasa Departemen Pendidikan Nasional

[16] Yulianti, Ing. (2015) "Pewarisan Nilai-Nilai Budaya Masyarakat Adat Cikondang dalam Pembelajaran Sejarah Madrasah Aliyah AlHijrah" Jurnal Candrasangkala Pendidikan Sejarah 1 (1), 112-133 